\title{
Mahkamah Konstitusi dalam Dua Rupa: The Instigator dan Agent of Social Change
}

\author{
Abdul Ghoffar \\ Mahkamah Konstitusi Republik Indonesia \\ JIn. Merdeka Barat No. 6, Jakarta Pusat, DKI Jakarta 10110 \\ abdulghoffarmk@gmail.com
}

\begin{abstract}
After more than a decade that Constitutional Court (MK) carries out its constitutional duties, this institution that was formed on 13 August 2003 has issued thousands of decisions The main problems in this research are, first, how is the role of the Constitutional Court on social change in society? Second, as a judicial institution, what kind of change model that the Constitutional Court does; is it the Instigator of Social Change or Agent of Social Change? Third, does the society prefer the role of the Constitutional Court as Instigator of Social Change or Agent of Social Change? The research method used in this research was normative-juridical research method. The results of the research concluded that, first, as a juridicial institution, the Constitutional Court has a significant role in making social changes to society. There are at least two decisions issued by the Constitutional Court that have changed public attitude, namely Decision of the Constitutional Court No 46/ PUU-VIII/2010 on "Children outside of Marriage" and Decision of the Constitutional Court No 47-81/PHPU.A-VII/2009 on "About Noken System". Second, in making such social changes, there are at least two models used by the Constitutional Court, namely playing the roles as Instigator of Social Change and Agent of Social Change. Third, society prefers the Constitutional Court to serve as Agent of Social Change rather than as Instigator of Social Change.
\end{abstract}

Keywords: Social change; Constitutional Court; Indonesian

\section{Abstrak}

Setelah lebih dari satu dasawarsa Mahkamah Konstitusi (MK) menjalankan tugas konstitusionalnya, lembaga yang dibentuk pada 13 Agustus 2003 ini realitanya telah mengeluarkan ribuan putusan. Pokok permasalahan dalam penelitian ini, pertama, bagaimana peran Mahkamah Konstitusi terhadap perubahan sosial di masyarakat? Kedua, sebagai lembaga peradilan, model perubahan seperti apa yang dilakukan oleh Mahkamah Konstitusi, apakah Instigator of Social Change atau Agent of Social Change? Ketiga, masyarakat lebih suka peran MK sebagai Instigator of Social Change atau Agent of Social Change? Metode penelitian yang digunakan dalam penelitian ini adalah metode penelitian normatif-yuridis. Hasil penelitian menyimpulkan bahwa, pertama, sebagai lembaga peradilan, MK mempunyai peran yang cukup besar dalam melakukan perubahan sosial terhadap masyarakat. Sedikitnya ada dua putusan MK yang telah mengubah perilaku masyarakat, yaitu Putusan MK Nomor 46/PUU-VIII/2010 tentang "Anak di luar Perkawinan" dan Putusan MK Nomor 47-81/PHPU.A-VII/2009 tentang "Tentang Sistem Noken". Kedua, dalam melakukan perubahan sosial tersebut, sedikitnya ada dua model yang dilakukan oleh MK, yaitu memainkan peran sebagai Instigator of Social Change dan Agent of Social Change. Ketiga, masyarakat lebih suka peran MK sebagai Agent of Social Change daripada peran MK sebagai Instigator of Social Change.

Kata-kata Kunci: Perubahan social; Mahkamah Konstitusi; Indonesia 


\section{Pendahuluan}

Dalam sebuah negara modern, konstitusi merupakan hukum tertinggi. Robert D. Cooter, dalam bukunya The Strategic Constitution, memberikan gambaran bagaimana sebuah konstitusi bila dibandingkan dengan peraturan perundangundangan yang lain. Pertama, konstitusi harus mengandung norma yang lebih umum daripada peraturan yang lain. Konstitusi mengatur atau memberi wewenang untuk pejabat dan mengakui hak-hak dasar warga negara, sementara peraturan perundang-undangan lainnya mengatur terkait perilaku atau pembuatan kebijakan. Kedua, konstitusi mengalahkan hukum lainnya, termasuk mengalahkan hukum internasional. Ketiga, konstitusi biasanya lebih mengakar daripada hukum lainnya, dalam arti tidak mudah berubah.

Ciri pertama dan kedua, sangat berhubungan dengan ciri ketiga. Sebagai hukum yang lebih umum dan kuat, perubahan di dalamnya menyebabkan gangguan yang lebih besar. Untuk menghindari gangguan, perubahan konstitusi harus lebih lambat dari pada hukum lainnya. Oleh sebab itu, mengubah konstitusi biasanya memerlukan prosedur yang lebih berat dan biaya yang lebih besar daripada perubahan UU atau peraturan perundang-undangan lainnya. ${ }^{1}$

Kriteria umum yang digambarkan oleh Robert D. Cooter tersebut juga pernah dialami Indonesia. Untuk melakukan perubahan UUD 1945 pada 1998, harus dimulai dengan menumbangkan Presiden Soeharto pada 1997. Keberhasilan tersebut tidak gratis: banyak nyawa melayang, triliun rupiah harta tertumpah.

Selama 4 tahun dari 1998 sampai 2002, Majelis Permusyawaratan Rakyat (MPR) melakukan perubahan UUD. Melihat dari besarnya jumlah pasal dan ayat yang diubah maupun ditambah, perubahan tersebut telah mengubah corak ketatanegaraan bangsa ini. Sebelum perubahan, UUD 1945 hanya terdiri dari 16 bab, 37 pasal dan 47 ayat ditambah 4 pasal Aturan Peralihan dan 2 ayat Aturan Tambahan. Setelah 4 kali perubahan, UUD 1945 menjadi 20 bab, 73 pasal, 171 ayat ditambah 3 pasal Aturan Peralihan dan 2 pasal Aturan Tambahan. Artinya, ada 20 bab, 73 pasal, 171 ayat, 3 pasal Aturan Peralihan dan 2 pasal Aturan Tambahan

${ }^{1}$ Robert D. Cooter, The Strategic Constitution (New Jersey: Princeton University Press, 2000), hlm. 19-20. Lihat juga Abdul Ghoffar, "Kejujuran dalam Bingkai Hak Memilih-Dipilih (Pelajaran dari Pemilukada Bengkulu Selatan)”, Jurnal Konstitusi Vol. 8 No. 1, 2011, hlm. 84-85. 
yang harus diterima sebagai bagian dari payung bangsa ini dalam melakukan setiap tindakannya.

Pada perubahan tahap ketiga 2001, MPR melakukan perubahan mendasar terhadap UUD 1945 yakni terkait dengan kedaulatan, perombakan parlemen, pemilihan Presiden secara langsung, dan membentuk lembaga baru yang bernama Mahkamah Konstitusi (MK) yang salah satu kewenangannya adalah untuk menguji UU terhadap UUD.

Kewenangan pengujian ini pada hakikatnya telah menempatkan UUD 1945 sebagai konstitusi yang hidup. Menurut David A. Strauss dalam bukunya, The Living Constitution, sebuah konstitusi dikatakan hidup jika bisa menyesuaikan dengan keadaan atau kondisi yang baru, tanpa harus secara resmi diubah. Kemampuan seperti ini menjadi keharusan karena jalur amandemen untuk melakukan perubahan konstitusi sangat sulit dilakukan setiap saat.

Untuk menyesuaikan tersebut, telah disediakan mekanisme resmi untuk melakukan perubahan kontitusi yakni amandemen. Akan tetapi dalam perakteknya, amandemen tidak bisa dilakukan setiap saat. Ada prosedur yang harus dilalui. Sementara itu, dunia telah berubah dengan cara yang tak terhitung. Hal ini kemudian dirasa sangat menyulitkan. Ada beda yang sangat mendasar antara kondisi Amerika dulu dengan sekarang. Telah terjadi pertumbuhan penduduk berkali lipat, telah terjadi perubahan dalam bidang teknologi, situasi internasional, ekonomi, termasuk adat istiadat sosial yang juga terus berubah dengan sangat cepat, dengan cara-cara yang tidak bisa diduga sebelumnya.

Fenomena seperti inilah yang oleh Strauss dikatakan sebagai sesuatu yang tidak realistis jika hanya mengharapkan proses amandemen yang rumit untuk mengawal perubahan zaman. Konstitusi harus bisa menjawab perubahan yang terjadi tanpa melalui prosedur yang rumit. Konstitusi harus berubah dan terus berubah. Jika tidak berubah, menurut Strauss, akan sangat merugikan masyarakat yang pada gilirannya masyarakat akan mengabaikan isi konstitusi tersebut, atau lebih buruk dari itu, yakni konstitusi menjadi penghambat kemajuan dan 
menyulitkan warga negara untuk melakukan hal baik. Di situlah kehadiran MK sangat dibutuhkan. ${ }^{2}$

Setelah lebih dari satu dasawarsa MK menjalankan tugas konstitusionalnya untuk menjaga dan menegakkan konstitusi, lembaga yang baru dibentuk pada 13 Agustus 2003 ini rupanya telah mengeluarkan banyak putusan. Berdasarkan data yang di-release MK, sejak 2003 hingga 18 Desember 2013, lembaga ini telah menangani 1.466 perkara, dengan perincian: 641 perkara Pengujian UndangUndang (44\%), 24 perkara Sengketa Kewenangan Lembaga Negara (1\%), 116 perkara Perselisihan Hasil Pemilihan Umum Legislatif dan Presiden/Wakil Presiden $(8 \%),{ }^{3}$ serta 685 perkara Perselisihan Hasil Pemilihan Umum Kepala Daerah $(47 \%) .4$

Dari 1.466 perkara yang telah diputus, terdapat 246 perkara dikabulkan $(18,8 \%), 15$ putusan sela $(1,1 \%), 703$ perkara ditolak (53,8\%), 338 perkara tidak dapat diterima $(25,9 \%)$, dan 5 perkara dinyatakan gugur $(0,4 \%)$. Sedangkan ketetapan terdiri dari 75 perkara ditarik kembali $(89 \%)$ dan 9 perkara dinyatakan tidak berwenang $(11 \%){ }^{5}$

Dari sekian banyak putusan tersebut, tidak sedikit yang mengundang kontroversi. Ada yang pro, juga tidak sedikit yang kontra. Meski demikian, MK tetap bergeming, sebab putusan MK - sebagaimana disebut dalam Pasal 24C Ayat (1) UUD 1945 - bersifat final dan mengikat sejak diucapkan dan tidak ada upaya hukum lain. Oleh karenanya, apapun putusan yang dikeluarkan oleh MK harus dianggap benar, sampai ada putusan berikutnya yang menganulir putusan tersebut.

Dalam tulisan ini, penulis tidak akan membahas seluruh putusan MK, tetapi hanya akan melihat dari sudut peran lembaga peradilan terhadap perubahan sosial di masyarakat. Setelah melakukan penelusuran dari berbagai referensi yang ada penulis menemukan salah satu artikel yang ditulis oleh Ronald Sackville, Hakim

\footnotetext{
${ }_{2}^{2}$ David A. Strauss, The Living Constitution (New York: Oxford University Press, 2000), hlm. 1-2. Kajian lebih dalam seputar ini bisa baca tulisan Penulis dengan judul Konstitusi Yang Bernyawa di Majalah Konstitusi Edisi Mei tahun 2012.

${ }^{3}$ Dalam satu perkara Perselisihan hasil Pemilihan Umum Legislatif terdapat banyak kasus. Misalnya pada tahun 2009 terdapat 71 perkara yang didalamnya memuat 657 kasus.

${ }^{4}$ Refleksi 2013 dan Proyeksi 2014 Mahkamah Konstitusi Menjaga Independensi Mahkamah Konstitusi Menyongsong Pemilu 2014, Mahkamah Konstitusi, Jakarta, 2014, hlm. 26.

${ }^{5}$ Ibid.
} 
Federal Court di Australia. Dalam artikel yang diberi judul Courts and Social Change, ia memulai dengan sebuah pengantar yang mengatakan bahwa hubungan antara pengadilan dan perubahan sosial setidaknya bisa dilihat dari dua perspekstif. Pertama, bagaimana peradilan merespon perubahan sosial yang terjadi secara nyata di tengah-tengah masyarakat. Kedua, apakah pengadilan bisa melakukan perubahan sosial. Pertanyaan tersebut disampaikan oleh Ronald Sackville dengan menggunakan obyek penelitian di negaranya yakni Australia.

Dalam konteks Indonesia, Penulis tertarik ingin melakukan penelitian serupa dengan mengambil sudut pandang atau obyek penelitian terhadap putusanputusan yang dikeluarkan oleh Mahkamah Konstitusi. Selain itu, Peneliti juga akan memaparkan sistem hukum apa yang sekarang dianut oleh Indonesia, khususnya setelah perubahan UUD NRI Tahun 1945 yang melahirkan MK. Urgensi menjelaskan sistem hukum ini dianggap penting, sebab sejatinya Australia adalah penganut common law system. Sementara Indonesia, oleh sebagian kalangan, dikatakan sebagai penganut civil law system.

\section{Rumusan Masalah}

Dari latar belakang penelitian di atas, ada tiga persoalan yang diteliti oleh peneliti. Pertama, bagaimana peran Mahkamah Konstitusi terhadap perubahan sosial di masyarakat? Kedua, sebagai lembaga peradilan, model perubahan seperti apa yang dilakukan oleh Mahkamah Konstitusi, apakah Instigator of Social Change atau Agent of Social Change? Ketiga, masyarakat lebih suka peran MK sebagai Instigator of Social Change atau Agent of Social Change?

\section{Tujuan Penelitian}

Berdasarkan topik serta uraian mengenai latar belakang dan rumusan masalah yang telah diuraikan di atas, secara implisit sebenarnya sudah menggambarkan tujuan dari Penelitian ini, yaitu: pertama, untuk mengetahui peran Mahkamah Konstitusi terhadap perubahan sosial di masyarakat. Kedua, untuk mengetahui dan mengidentifikasi model perubahan seperti apa yang dilakukan oleh Mahkamah Konstitusi, apakah Instigator of Social Change atau Agent of Social 
Change. Ketiga, untuk mengetahui masyarakat lebih suka peran MK sebagai Instigator of Social Change atau Agent of Social Change.

\section{Metode Penelitian}

Penelitian dengan judul "Mahkamah Konstitusi Dalam Dua Rupa: Instigator dan Agent of Social Change" ini, adalah penelitian hukum normatif. ${ }^{6}$ Penelitian ini menitik beratkan pada kajian seputar model putusan MK yang mempengaruhi perubahan masyarakat di Indonesia.

Pendekatan yang digunakan dalam penelitian ini adalah pendekatan yuridis, ${ }^{7}$ berdasarkan ruang lingkup dan identifikasi permasalahan yang ada. Pendekatan akan mempergunakan bahan hukum primer, ${ }^{8}$ bahan hukum sekunder ${ }^{9}$ dan bahan hukum tersier. ${ }^{10}$

Bahan hukum primer adalah data yang diperoleh dari konstitusi dan peraturan perundang-undangan di Indonesia. Sementara bahan hukum sekunder antara lain diperoleh dari dokumen-dokumen resmi, buku-buku, hasil-hasil Penelitian yang berwujud laporan, buku harian, serta konstitusi atau peraturan perundang-undangan negara-negara lain terutama terkait dengan peran putusan MK dalam perubahan sosial di Indonesia. Khusus untuk mengetahui persepsi masyarakat terhadap putusan MK yang sedang diteliti oleh MK, penulis juga menggunakan sistem yang disediakan oleh mesin pencari google.

\footnotetext{
${ }^{6}$ Menurut Soerjono Soekanto dan Sri Mamuji, penelitian hukum normatif seperti ini biasanya meneliti dalam hal; penelitian terhadap asas-asas hukum, penelitian terhadap sistematik hukum, penelitian terhadap taraf sinkronisasi vertikal dan horisontal, perbandingan hukum, dan sejarah hukum. Soerjono Soekanto, dan Sri Mamuji, Penelitian Hukum Normatif; Suatu Tinjanan Singkat, cet. ke-6, RajaGrafindo Persada, Jakarta, 2003, hlm. 14. Lihat pula Soerjono Soekanto, Pengantar Penelitian Hukum, Jakarta, UI-Press, 1986. Lihat juga Burhan Ashshofa, Metode Penelitian Hukum, cet. ke-4, Rineka Cipta, Jakarta, 2004, hlm. 12.

7 Peter Mahmud Marzuki menggunakan istilah pendekatan undang-undang (statute approach). Menurutnya, statute approach dilakukan untuk menelaah semua undang-undang dan regulasi yang bersangkut paut dengan isu hukum yang sedang ditangani. Bagi penelitian untuk kegiatan praktis, pendekatan undang-undang ini akan membuka kesempatan bagi peneliti mempelajari adakah konsistensi dan kesesuaian antara suatu undang-undang dengan undang-undang lainnya atau antara undang-undang dengan undang-undang dasar atau antara regulasi dan undang-undang. Hasil dari telaah tersebut merupakan suatu argument untuk memecahkan isu yang dihadapi. Peter Mahmud Marzuki, Penelitian Hukum, Prenada Media, Jakarta, 2005, hlm. 93.

8 Bahan hukum primer adalah bahan-bahan hokum yang mengikat, berupa; norma/kaedah dasar, peraturan dasar, peraturan perundang-undangan, dan lain sebagainya. Valerine J.L. Kriekhof, dkk., "Metode Penelitian Hukum (Seri Buku Ajar)," Buku A, Fakultas Hukum Universitas Indonesia, Depok, 2000, hlm. 27.

${ }^{9}$ Bahan hukum sekunder adalah bahan-bahan yang memberikan penjelasan mengenai bahan primer, yang berupa; buku, skripsi, thesis, dan lain-lain. Ibid, hlm. 28.

${ }^{10}$ Bahan hukum tersier adalah bahan-bahan yang memberikan petunjuk maupun penjelasan terhadap bahan hukum primer dan sekunder atau disebut juga sebagai bahan penunjang, yang berupa; Kamus, Eksiklopedi, Indeks, dan lain-lain. Ibid.
} 


\section{Hasil Penelitian dan Pembahasan}

\section{Sistem Hukum}

Sedikitnya ada dua kutub besar dalam strategi atau sistem hukum di dunia. Kutub pertama adalah kutub legisme atau civil law (hukum tertulis dan kepastian hukum), sedangkan kutub kedua adalah kutub common law (rasa keadilan). Kutub pertama yang dianut di kawasan Eropa Kontenantal disebut negara hukum "Rechsstaat", 11 sedangkan kutub kedua yang dianut di Anglo Saxon disebut negara hukum "the rule of law". Dewasa ini garis batas antara kedua sistem tersebut mulai kabur karena ada keniscayaan untuk saling mewarnai. ${ }^{12}$

Pada masa lalu, Indonesia memang cenderung mengikuti paham Eropa Kontinental karena lama dijajah oleh Belanda. Dalam pandangan legisme,13 seakan-akan hukum yang benar adalah hukum tertulis. Sekalipun demikian, sepanjang perjalanan sejarah, karena akar budaya hukum Indonesia adalah tidak tertulis, maka dalam praktiknya selalu terjadi tarik menarik. Karena itu, sejak dulu di Indonesia, para hakim dalam memutus perkara diharuskan berpedoman pada undang-undang dan aturan tertulis lainnya, tetapi hakim juga harus diperbolehkan untuk menggali sendiri hukum yang hidup berada di tengah-tengah masyarakat. ${ }^{14}$

Oleh karenanya, strategi hukum di Indonesia ada dua, yakni legisme (civil law), dan juga rasa keadilan atau keadilan substantif (common law). Inilah mungkin yang bisa disebut sebagai strategi prismatik yang pernah dilontarkan oleh Fred W.

${ }^{11}$ Banyak sebutan yang merujuk pada istilah Negara hukum. di Jerman Negara Hukum disebut Rechtsstaat, di Perancis dikenal dengan istilah Etat de droit, dan di Inggris (juga Amerika Serikat) disebut "The Rule of Law". Ketiga istilah tersebut secara umum mengandung pengertian yang sama, yaitu kedaulatan atau supremasi hukum atas orang dan pemerintah terikat oleh hukum. Baca bukunya, Michel Rosenfeld, Constitutional Adjudication in Europe and the United States: Paradoxes and Contrasts, dalam European and US Constitutionalism, Georg Nolte (ed.), Cambridge University Press, New York, 2005, hlm. 204. Sementara itu, Francis G. Jacobs, melihat bahwa the rule of law sebagai nilai dasar yang diakui secara global. Namun tidak ada satu pun kesepatan universal tentang arti dari istilah tersebut. Meski demikian, dari berbagai pandangan yang ada, bisa ditarik satu kesamaan bahwa the rule of law menjadi syarat utama dari Negara demokrasi. Untuk lebih jelasnya bisa dibaca di Francis G. Jacobs, The Sovereignty of law: the European way, Cambridge University Press, London, 2007, hlm. 7.

12 Moh. Mahfud MD, Inilah Hukum Progresif Indonesia dalam Moh. Mahfud MD, dkk, Dekonstruksi dan Gerakan Pemikiran Hukum Progresif, Thafa Media dan Konsorsium Hukum Progresif Universitas Diponegoro, Semarang, 2013, hlm. 8.

13 Satjipto Rahardjo menggunakana istilah legisme-formal, yaitu memberikan pengutamaan kepada pembacaan dari apa yang tertulis. Cara demikian memang tidak bisa disalahkan, tetapi yang menjadi masalah jika kita membiarkan diri secara total diikat oleh undang-undang atau prosedur. Satjipto Rahardjo, Biarkan Hukum Mengalir: Catatan Kritis tentang Pergulatan Manusia dan Hukum, Penerbit Buku Kompas, Jakarta, 2007, hlm. 86-87.

${ }^{14}$ Ibid., hlm. 9. 
Riggs. ${ }^{15}$ Konsep legisme menjadi dasar hukum rechtsstaat. Sedangkan negara hukum dengan keadilan susbtantif disebut the rule of law. Jadi, the rule of law dan rechtsstaat merupakan dua hal yang berbeda. Meskipun terjemahannya dalam bahasa Indonesia sama-sama negara hukum. Rechtsstaat sejatinya menitikberatkan pada hukum tertulis, ${ }^{16}$ sedangkan the rule of law lebih menekankan pada keyakinan hakim untuk menggali keadilannya sendiri. ${ }^{17}$

Sebelum UUD 1945 dilakukan perubahan pada tahun 1999-2002, menurut Mahfud MD, kita mengenali Penjelasan UUD 1945 yang di dalamnya adalah istilah rechtsstaat. Namun seiring dengan dilakukannya perubahan, Penjelasan tersebut ditiadakan dengan memasukkan isi Penjelasan kedalam pasal-pasal UUD 1945. Istilah rechtsstaat diubah menjadi negara hukum dan termuat dalam Pasal 1 ayat (3) UUD 1945, “Negara Indonesia adalah negara hukum."18

Menurut Mahfud MD, tidak dicantumkannya istilah rechtsstaat tersebut memang sengaja dilakukan untuk menunjukkan bahwa Indonesia itu bisa rechtsstaat, bisa juga the rule of law. Indonesia itu bisa menganut faham legisme yang mana kebenaran itu ada di undang-undang dan peraturan tertulis, tetapi juga menganut paham bahwa hakim bisa mencari keadilan sendiri. Dengan demikian lebih fleksibel. Inilah konsep prismatik. ${ }^{19}$ Dengan demikian, MK bisa membuat putusan-putusan yang mendasarkan pada hukum yang berkembang di masyarakat, atau berdasar hati nurani hakim dengan mengendepankan rasa keadilan, meski itu semua harus keluar dari aturan tertulis yang ada.

${ }^{15}$ Lihat Fred W. Riggs, Administration in Developing Countries: The Theory of Prismatic Society, Houghton Mifflin Company, Boston, 1964.

${ }^{16}$ J.B.J.M. ten Berge menyatakan salah satu prinsip negara hukum adalah adanya asas legalitas. Asas ini menghendaki undang-undang secara umum harus memberikan jaminan terhadap warga negara dari tindakan pemerintah yang sewenang-wenang, kolusi, dan berbagai jenis tindakan yang tidak benar. Sehingga pelaksanaan wewenang oleh organ pemerintahan harus ditemukan dasarnya pada undang-undang tertulis. Untuk lebih jelasnya lihat J.B.G.M. ten Berge, Besturen door de Overheid, W.E.J.Tjeenk Willink, Deventer, 1996, hlm 34-38 dalam Ridwan HR, Hukum Administrasi Negara, Raja Grafindo Persada, Jakarta, 2011, hlm. 9, sebagaimana dikutip oleh Nafiatul Munawaroh dan Maryam Nur Hidayati, "Integrasi Pengujian Peraturan Perundang-Undangan di Mahkamah Konstitusi sebagai Upaya Pembangunan Hukum Indonesia”, Jurnal Hukum Ius Quia Iustum No. 2 Vol. 22 April 2015, hlm. 259.

${ }^{17}$ Moh. Mahfud MD, Inilah Hukum Progresif... op cit. hlm. 8.

${ }^{18}$ Ibid., hlm. 9.

${ }^{19}$ Ibid., hlm. 11. 


\section{Mahkamah Konstitusi dan Perubahan Sosial}

Terdapat banyak perdebatan mengenai peran lembaga peradilan dalam melakukan perubahan sosial. Bagi negara-negara yang menganut sistem common law, pengadilan sangat berperan dalam melakukan perubahan sosial, misalnya di Amerika Serikat.

Gerald N. Rosenberg, dalam bukunya The Hollow Hope: Can Courts Bring About Social Change? menulis tentang perubahan sosial yang diakibatkan dari putusan peradilan khususnya putusan mahkamah Agung Amerika Serikat. Menurutnya, kelebihan yang dimiliki oleh Mahkamah Agung Amerika Serikat (baca; lembaga peradilan) dalam perubahan sosial adalah lebih leluasa dalam membuat putusan yang berpengaruh pada perubahan sosial, bahkan bila perlu melawan mayoritas, tanpa harus memikirkan apakah putusannya tersebut disukai oleh masyarakat atau tidak. ${ }^{20}$

Hal demikian tentu berbeda dengan para pejabat yang dipilih (seperti Presiden dan Parlemen) yang setiap kebijakannya akan mendasarkan pada suara mayoritas warga negara. Seperti peradilan hanya mengabdi pada suara keadilan. Selain itu, lembaga peradilan juga mampu menghasilkan perubahan sosial dan politik yang signifikan dan dasyat, meski tanpa dukungan aktif dari pemimpin politik, lembaga negara lainnya, dan birokrasi. ${ }^{21}$

Rosenberg mencontohkan putusan Mahkamah Agung Amerika Serikat dalam kasus Brown v. Board of Education (1954) yang menolak sistem terpisah sekolah kulit putih dan kulit berwarna, dan berimplikasi pada pembatalan doktrin "terpisah tapi sederajat" yang dulu muncul akibat Putusan Mahkamah Agung dalam kasus Plessy v. Ferguson tahun 1896.22 Putusan Brown v. Board of Education mengakhiri diskriminasi ras dalam pendidikan, pemilu, transportasi, akomodasi umum, dan perumahan. ${ }^{23}$

\footnotetext{
${ }^{20}$ Gerald N. Rosenberg, The Hollow Hope: Can Courts Bring About Social Change? University of Chicago Press, Chicago, 1991, hlm. 22.

${ }^{21}$ Ibid.

22 Sebuah keputusan Mahkamah Agung pada 1896 yang memerintah "berbeda tetapi sederajat" fasilitas untuk Afrika Amerika konstitusional di bawah Amandemen Keempat Belas, ia memiliki efek melegalkan pemisahan dan menyebabkan pengesahan undang-undang diskriminatif lebih dikenal sebagai hukum Jim Crow. http://id.termwiki.com/ID:Plessy_v._Ferguson. Diakses pada 24 Januari 2014.

${ }^{23}$ Gerald N. Rosenberg, The Hollow Hope..., Op. Cit., hlm. 70-71.
} 
Di benua lain, seorang hakim Federal Court di Australia, Ronald Sackville, menulis sebuah artikel Courts and Social Change. Sackville meneliti tentang peran pengadilan sebagai pemantik atau mempengaruhi perubahan sosial (Courts as Instigator of Social Change) dan pengadilan sebagai agen perubahan sosial (Courts as Agent of Social Change). ${ }^{24}$

Sackville membuat pembedaan makna atas kedua istilah tersebut. Instigator perubahan sosial dimaknainya sebagai kewenangan yang diberikan kepada pengadilan untuk mempengaruhi perubahan sosial, khusunya dalam hal mengubah norma-norma sosial dan nilai-nilai yang hidup dalam masyarakat. Sackville dalam tulisan tersebut mengakui bahwa di Australia sendiri terjadi perbedaan pendapat atas peran ini. Di satu pihak, ada beberapa hakim yang tidak terlalu mengkhawatirkan peran pengadilan tersebut, akan tetapi di pihak lain banyak juga hakim yang tidak menganjurkan pengadilan untuk menggunakan perannya tersebut karena khawatir putusan peradilan tersebut tidak diterima oleh masyarakat. ${ }^{25}$

Sedangkan peradilan sebagai Agent of Social Change dimaknai oleh Sackville sebagai kewenangan yang dimiliki oleh pengadilan sebagai agen untuk perubahan sosial dengan mendasarkan pada nilai-nilai yang tumbuh dan hidup ditengahtengah masyarakat. Putusan pengadilan diharapkan dapat merespon terhadap perubahan sosial yang terjadi di masyarakat.

Dengan demikian secara sederhana bisa difahami, menurut Sackville, pembeda antara peradilan sebagai Instigator of Social Change dengan Agent of Social Change adalah terletak pada inisiatornya. Kalau instigators, peradilan menjadi aktif (judicial activisme) melalui putusan-putusannya mempengaruhi perubahan sosial. Sementara peradilan sebagai Agent of Social Change lebih menekankan peradilan menjadi "tukang stempel" perubahan yang sudah ada di masyarakat untuk diberikan legitimasi melalui putusannya. ${ }^{26}$

Mengakhiri artikelnya, Sackville mengeluarkan tesis bahwa lembaga peradilan lebih disukai jika menggunakan peran sebagai Agent of Social Change atau

${ }^{24}$ Justice Ronald Sackville, "Courts and Social Change", dalam Federal Law Review Volume 33. hlm. 374. Content downloaded/printed from HeinOnline (http://heinonline.org), Mon Jan 20 03:33:42 2014.

${ }^{25}$ Ibid.

${ }^{26}$ Ibid. 
peradilan yang merespon perubahan sosial ketimbang peradilan sebagai Instigator of Social Change pengadilan terlalu mengubah nilai dan norma yang yang tumbuh di masyarakat. ${ }^{27}$ Lalu bagaimana dengan di MK? Berikut akan disajikan beberapa putusan untuk melihat apakah lembaga ini memainkan kedua peran tersebut, sekaligus untuk mengetahui penerimaan masyarakat dilihat dari pemberitaan dan tulisan di media online.

\section{Tanggung Jawab Ayah Biologis}

Pada mulanya sesuai dengan Pasal 43 ayat (1) UU No. 1 Tahun 1974 tentang perkawinan, "anak yang dilahirkan di luar perkawinan hanya mempunyai hubungan perdata dengan ibunya dan keluarga ibunya." Namun setelah adanya Putusan MK Nomor 46/PUU-VIII/ 2010 Tentang Pengujian UU No. 1 Tahun 1974 tentang Perkawinan (selanjutnya akan disebut Putusan MK tentang anak diluar kawin) yang diucapkan secara terbuka 17 Februari 2012, ketentuan tersebut berubah. 28

Adalah Aisyah Mochtar alias Machica binti H. Mochtar Ibrahim atau yang akrap disapa Machicah Mochtar, penyanyi pada era 80-an, bersama anak semata wayangnya Muhammad Iqbal Ramadhan bin Moerdiono, mengajukan permohonan ke MK terhadap dua pasal yang tertuang di dalam UU Perkawinan, yaitu Pasal 2 ayat (2) UU 1/1974 yang menyatakan, "Tiap-tiap perkawinan dicatat menurut peraturan perundang-undangan yang berlaku", dan Pasal 43 ayat (1) UU 1/1974 yang menyatakan, "Anak yang dilahirkan di luar perkawinan hanya mempunyai hubungan perdata dengan ibunya dan keluarga ibunya", khususnya mengenai hak untuk mendapatkan status hukum anak. ${ }^{29}$

Terhadap permohonan tersebut, MK berpendapat bahwa hubungan anak dengan seorang laki-laki sebagai bapak tidak semata-mata karena adanya ikatan perkawinan, akan tetapi dapat juga didasarkan pada pembuktian adanya hubungan darah antara anak dengan laki-laki tersebut sebagai bapak. Dengan demikian, terlepas dari soal prosedur/administrasi perkawinannya, anak yang

${ }^{27}$ Ibid., hlm. 389-390.

28 Putusan MK Nomor 46/PUU-VIII/2010 Tentang Pengujian UU No. 1 Tahun 1974 tentang Perkawinan.

${ }^{29}$ Ibid., hlm. 33 
dilahirkan harus mendapatkan perlindungan hukum. Jika tidak demikian, maka yang dirugikan adalah anak yang dilahirkan di luar perkawinan, padahal anak tersebut tidak berdosa karena kelahirannya di luar kehendaknya. ${ }^{30}$

Anak yang dilahirkan tanpa memiliki kejelasan status ayah seringkali mendapatkan perlakuan yang tidak adil dan stigma di tengah-tengah masyarakat. Hukum harus memberi perlindungan dan kepastian hukum yang adil terhadap status seorang anak yang dilahirkan dan hak-hak yang ada padanya, termasuk terhadap anak yang dilahirkan meskipun keabsahan perkawinannya masih dipersengketakan.

Menurut MK, Pasal 43 ayat (1) UU 1/1974 yang menyatakan, "Anak yang dilahirkan di luar perkawinan hanya mempunyai hubungan perdata dengan ibunya dan keluarga ibunya," harus dibaca, "Anak yang dilahirkan di luar perkawinan mempunyai hubungan perdata dengan ibunya dan keluarga ibunya serta dengan laki-laki sebagai ayahnya yang dapat dibuktikan berdasarkan ilmu pengetahuan dan teknologi dan/atau alat bukti lain menurut hukum mempunyai hubungan darah, termasuk hubungan perdata dengan keluarga ayahnya." 31

Sementara itu, terhadap dalil Pemohon terkait Pasal 2 ayat (2) UU 1/1974 tidak beralasan menurut hukum. Adapun Pasal 43 ayat (1) UU 1/1974 yang menyatakan, "Anak yang dilahirkan di luar perkawinan hanya mempunyai hubungan perdata dengan ibunya dan keluarga ibunya" adalah bertentangan dengan UUD 1945 secara bersyarat (conditionally unconstitutional) yakni inkonstitusional sepanjang ayat tersebut dimaknai menghilangkan hubungan perdata dengan laki-laki yang dapat dibuktikan berdasarkan ilmu pengetahuan dan teknologi dan/atau alat bukti lain menurut hukum mempunyai hubungan darah sebagai ayahnya. ${ }^{32}$

\section{Legitimasi Sistem Noken}

Noken adalah salah satu tradisi di masyarakat Papua yang dijadikan sistem dalam pemungutan suara. Sistem tersebut memberikan kepercayaan kepada pemimpin atau orang yang dituakan untuk memilih. Salah satu yang mempersulit penyelenggara Pemilu Papua adalah sistem Noken yang selama ini diterapkan.

\footnotetext{
${ }^{30}$ Ibid., hlm. 35.

${ }^{31}$ Ibid.

32 Ibid., hlm. 36.
} 
Selain itu, persoalan geografis dan data kependudukan juga menjadi masalah tersendiri. ${ }^{33}$ Saat ini, Noken telah dilegitimasi oleh MK melalui Putusan Nomor 4781/PHPU.A-VII/2009 Tentang Perselisihan Hasil Pemilihan Umum Anggota Dewan Perwakilan Daerah (selanjutnya akan disebut Putusan MK Tentang Sistem Noken).

Putusan ini sebagai respon dari permohonan yang diajukan oleh Pdt. Elion Numberi dan Hasbi Suaib, calon anggota DPD dari Provinsi Papua, dalam perkara Perselisihan Hasil Pemilihan Umum. Kedua Pemohon mempersoalkan hasil perolehan suaranya. Mereka mendalilkan bahwa mereka seharusnya lolos menjadi anggota Dewan Perwakilan Daerah sekiranya penghitungan suara dilakukan secara benar. 34

Pemohon I, Pdt. Elion Numberi, dengan registrasi Perkara Nomor 47/PHPU.A-VII/2009, mendalilkan bahwa telah terjadi kesalahan penetapan atas penghitungan suara fiktif dari Kabupaten Yahukimo oleh KPU Pusat sehingga merugikan peringkat suara Pemohon. Jumlah suara sah yang dimiliki Pemohon tanpa penghitungan fiktif dari Kabupaten Yahukimo adalah sebesar 195.428 suara menurut Rekapitulasi KPU Provinsi Papua dan 195.778 suara menurut penetapan KPU Pusat. ${ }^{35}$ Dengan jumlah ini, tanpa memperhitungkan penghitungan suara fiktif di Kabupaten Yahukimo, maka peringkat Pemohon berada di peringkat 4 (empat) atau berarti lolos menjadi anggota DPD-RI. Namun, dengan dimasukkannya penghitungan yang bermasalah dari Kabupaten Yahukimo, maka terdapat penambahan suara calon anggota DPD Paulus Yohannes Sumino sebesar 148.289 suara hanya dari Kabupaten Yahukimo, mengubah secara drastis perolehan calon anggota DPD Paulus Yohannes Sumino dari 107.580 suara sebelum ada penambahan suara dari Kabupaten Yahukimo menjadi 255.869 suara menurut

\footnotetext{
${ }^{33}$ Bagus Anwar Hidayatulloh, Kontroversi Putusan MK Tentang Pemilu Noken, http://hukum.kompasiana.com/2013/11/24/kontroversi-putusan-mk-tentang-pemilu-noken--610900.html. Diakses pada 21 Januari 2014.

34 Putusan MK Nomor 47-81/PHPU.A-VII/2009 Tentang Perselisihan Hasil Pemilihan Umum Anggota Dewan Perwakilan Daerah.

35 Putusan MK Nomor 47-81/PHPU.A-VII/2009 Tentang Perselisihan Hasil Pemilihan Umum Anggota Dewan Perwakilan Daerah, hlm. 6. http://www.mahkamahkonstitusi.go.id/index.php?page $=$ web.Putusan\&id =1\&kat=1\&cari=47-81\%2FPHPU.A-VII\%2F2009. Diakses pada tanggal 24 Januari 2014.
} 
Rekapitulasi KPU Provinsi Papua dan 256.027 suara menurut penetapan KPU Pusat. 36

Pemohon II, Hasbi Suaib, dengan Perkara Nomor 81/PHPU.A-VII/2009 mendalilkan bahwa proses penghitungan suara calon anggota DPD Provinsi Papua di Kabupaten Yahukimo, Kabupaten Tolikara, Kabupaten Mimika dan Kabupaten Nabire dilaksanakan tidak sesuai dengan Undang-Undang Nomor 10 Tahun 2008 tentang Pemilihan Umum Anggota DPR, DPD dan DPRD, karena berdasarkan keterangan saksi Pemohon, di empat kabupaten tersebut, KPUD tidak melakukan penghitungan dan rekapitulasi perolehan suara calon anggota DPD. Rekapitulasi hanya dilakukan di tingkat KPU Provinsi Papua. Bukti dari tidak dilakukannya rekapitulasi tersebut, hingga batas waktu yang ditentukan, baik Pemohon maupun saksi Pemohon, tidak pernah mendapatkan hasil rekapitulasi perolehan suara calon anggota DPD. ${ }^{37}$

Terhadap Permohonan tersebut, MK kemudian mengeluarkan putusan sela yang pada intinya memerintahkan pemungutan suara ulang di banyak distrik, dan penghitungan suara ulang di beberapa distrik lainnya di Kabupaten Yahukimo karena secara nyata tidak diselenggarakan pemilihan umum. Selain itu juga, di banyak Distrik lainnya juga telah terjadi perbedaan rekapitulasi penghitungan hasil pemilihan umum.

Dalam persidangan di MK juga ditemukan fakta hukum bahwa pemilihan umum di Kabupaten Yahukimo umumnya tidak dilakukan dengan cara pencontrengan pada surat suara, melainkan dilakukan penentuan suara dengan cara "kesepakatan warga" atau "aklamasi" oleh setiap perwakilan kelompok masyarakat. ${ }^{38}$

Fakta hukum tersebut diperoleh MK dari berdasarkan keterangan KPU Kabupaten Yahukimo dan saksi-saksi yang menyatakan bahwa pemilihan umum dilakukan tidak dengan cara pencontrengan pada surat suara, melainkan dilaksanakan dengan cara "kesepakatan warga" atau "aklamasi", ternyata hasilnya

\footnotetext{
${ }^{36}$ Ibid., hlm. 7.

${ }^{37}$ Ibid., hlm. 21-22.

38 Ibid., hlm. 45.
} 
tetap dimasukkan ke dalam rekapitulasi hasil penghitungan suara yang dilaksanakan pada 6 Mei 2009 di KPU Provinsi Papua.

Terhadap fakta hukum tersebut, MK berpendapat bahwa pemilihan umum di Kabupaten Yahukimo tidak diselenggarakan berdasarkan peraturan perundangundangan yang berlaku (UU 10/2008 yang telah diubah terakhir dengan Peraturan Pemerintah Pengganti Undang-Undang Nomor 1 Tahun 2009 tentang Perubahan Atas Undang-Undang Nomor 10 Tahun 2008 tentang Pemilihan Umum Anggota Dewan Perwakilan Rakyat, Dewan Perwakilan Daerah, dan Dewan Perwakilan Rakyat Daerah) karena tidak dengan cara pencontrengan surat suara, melainkan dengan "kesepakatan warga" atau "aklamasi" dan hasilnya tetap dimasukkan ke dalam rekapitulasi hasil penghitungan suara yang dilaksanakan pada tanggal 6 Mei 2009 di KPU Provinsi Papua. ${ }^{39}$

MK juga dapat memahami dan menghargai nilai budaya yang hidup di kalangan masyarakat Papua yang khas dalam menyelenggarakan pemilihan umum dengan cara atau sistem "kesepakatan warga" atau "aklamasi". Mahkamah menerima cara pemilihan kolektif ("kesepakatan warga" atau "aklamasi") yang telah diterima masyarakat Kabupaten Yahukimo tersebut, karena jika dipaksakan pemilihan umum sesuai dengan peraturan perundang-undangan yang berlaku dikhawatirkan akan timbul konflik di antara kelompok-kelompok masyarakat setempat. MK berpendapat, agar sebaiknya mereka tidak dilibatkan/dibawa ke sistem persaingan/perpecahan di dalam dan antar kelompok yang dapat mengganggu harmoni yang telah mereka hayati. Meski demikian, MK meminta agar penerimaan atas cara tersebut harus dilaksanakan dengan baik oleh penyelenggara pemilihan umum. ${ }^{40}$

\section{MK Sebagai Instigator of Social Change}

Dari putusan yang tersaji di atas, terhadap putusan Putusan MK Nomor 46/PUU-VIII/2010 yang memutus soal tanggung jawab ayah biologis bagi anak adalah putusan yang instigators. Putusan ini secara nyata telah mengubah perilaku sosial dengan memberi dampak positif pada anak yang lahir di luar perkawinan.

39 Ibid., hlm. 46.
40 Ibid., hlm. 47. 
Dikatakan sebagai putusan Instigator sebab putusan ini telah "melawan" mainstream hukum yang masih hidup dan dipegang kuat oleh masyarakat. Bukan hanya hukum negara, tetapi juga hukum agama. Di dalam Undang-Undang No. 1 Tahun 1974 tentang Perkawinan dikatakan bahwa anak yang sah adalah anak yang dilahirkan dalam atau sebagai akibat perkawinan yang sah (Pasal 42). Dalam pasal selanjutnya, Pasal 43 ayat (1) dikatakan, "anak yang dilahirkan di luar perkawinan hanya mempunyai hubungan perdata dengan ibunya dan keluarga ibunya."

Sementara dalam Kitab Undang-Undang Hukum Perdata (KUH Perdata) hubungan perdata anak dengan orang tuanya baru ada ketika ada pengakuan dari orang tuanya. Pasal 280 KUH Perdata mengatakan, "dengan pengakuan terhadap anak di luar kawin, terlahirlah hubungan perdata antara anak itu dan bapak atau ibunya." Akan tetapi, pengakuan tersebut tidak berlaku bagi anak yang dilahirkan dari perzinaan atau penodaan darah (incest, sumbang) sebagaimana diatur dalam Pasal $283 \mathrm{KUH}$ Perdata yang mengatakan, "Anak yang dilahirkan karena perzinaan atau penodaan darah (incest, sumbang), tidak boleh diakui tanpa mengurangi ketentuan Pasal 273 mengenai anak penodaan darah." 41

Hal demikian juga diatur di dalam hukum Islam. Dalam Pasal 99 Kompilasi Hukum Islam dijelaskan bahwa, "Anak yang sah adalah: a. anak yang dilahirkan dalam atau akibat perkawinan yang sah; $b$. hasil perbuatan suami isteri yang sah di luar rahim dan dilahirkan oleh isteri tersebut." Sedangkan Pasal 100 mengatakan, "Anak yang lahir di luar perkawinan hanya mempunyai hubungan nasab dengan ibunya dan keluarga ibunya." 42

Bisa dikatakan bahwa dalam putusan tersebut MK telah membuat "kebijakan" yang berpengaruh terhadap perubahan sosial. Sebab putusan tersebut secara nyata dan terang berlawanan dengan hukum positif maupun hukum yang yang dihidup ditengah-tengah masyarakat.

\section{MK Sebagai Agent of Social Change}

Selain memerankan fungsi Instigator of Social Change, jika dilihat dari putusan kedua, maka terlihat MK juga telah memerankan fungsi Agent of Social Change atau

41 KITAB UNDANG-UNDANG HUKUM PERDATA (Burgerlijk Wetboek voor Indonesie), buk.um.unsrat.ac.id/uu/kolonial_kuh_perdata.pdf., diakses pada tanggal 22 Januari 2014.

42 Kompilasi Hukum Islam, bukum.unsrat.ac.id/ma/kompilasi.pd., diakses pada tanggal 22 Januari 2014. 
peran Pengadilan sebagai agen untuk perubahan sosial dengan mendasarkan pada nilai-nilai yang tumbuh dan hidup di tengah-tengah masyarakat. Putusan Pengadilan yang merespon terhadap perubahan sosial yang terjadi di masyarakat.

Putusan MK No. 47-81/PHPU.A-VII/2009 yang memberi legitimasi atas sistem noken di Yahukimo Papua menjadi bukti nyata bahwa MK juga memerankan peran sebagai Agent of Social Change. Sebab, dalam putusan tersebut MK secara nyata memberi pembenaran terhadap budaya pemilihan yang tumbuh di tengah-tengah masyarakat di Yahukimo.

Noken adalah salah satu tradisi di masyarakat Papua yang dijadikan sistem dalam pemungutan suara. Sistem tersebut memberikan kepercayaan kepada pemimpin atau orang yang dituakan untuk memilih.

Sistem Pemilihan Umum yang menerapkan "Sistem Noken" dengan mewakilkan kepada kepala sukunya untuk memilih-oleh sebagian kalangan penganut demokrasi modern yang mengharuskan one man one vote one value - tentu itu dinilai sebagai bentuk pelanggaran dan bertentangan dengan nilai-nilai demokrasi yang dianutnya. Tetapi melalui putusannya, MK memberi legitimasi bahwa model pemilu seperti itu adalah sah karena sesuai dengan adat istidat yang ada, yang hidup, dan tumbuh di tengah-tengah masyarakat.

\section{Penerimaan Masyarakat}

Untuk mengetahui bagaimana peneriman masyarakat terhadap kedua fungsi yang diperankan oleh MK tersebut, Peneliti menggunakan metode penelitian dengan melihat seberapa banyak "pembicaraan" (pemberitaan, tulisan, artikel, jurnal, dan lain sebagainya) yang ada di internet dengan menggunakan mesin pencari (search engine) Google.

Menggunakan model penelitian seperti diakui diharapkan akan diketahui seberapa besar "pembicaraan" terkait putusan tersebut di media online. Semakin banyak "pembicaraan" yang dilakukan, oleh peneliti akan disimpulkan bahwa putusan tersebut lebih kontroversi dan lebih resisten, daripada yang tidak terlalu banyak "pembicaraan" di media online (internet). Semakin sedikit "pembicaraan" maka akan disimpulkan tingkat penerimaan masyarakat akan lebih besar. Artinya, putusan tersebut dinilai tidak "mengganggu" banyak kalangan di masyarakat. 
Selain itu peneliti juga akan menggunakan keyword "menolak" dan "menerima" dengan harapan diketahui lebih banyak mana "pembicaraan" yang menolak dan yang menerima. Penelitian dilakukan pada 23 Januari 2014 dari Pukul 09.00 sampai dengan Pukul 10.00 WIB dengan menggunakan bantuan mesin pencari Google, Peneliti menuliskan beberapa keyword dengan hasil sebagai berikut.

(1) Putusan MK 46/PUU-VIII/2010 Tentang Anak Di luar Kawin

(a) Keyword "Putusan MK Tentang Anak di Luar Perkawinan," mesin pencari Google menunjukkan 156,000 data (tulisan, artikel, jurnal, dan lain sebagainya) yang diupload di internet. ${ }^{43}$

(b) Keyword "Tanggung Jawab Ayah Biologis Pasca Putusan MK," mesin pencari Google menunjukkan 56,100 data (tulisan, artikel, jurnal, dan lain sebagainya). ${ }^{4}$

(c) Keyword "Menerima Putusan MK Tentang Anak Diluar Kawin," mesin pencari Google menunjukkan ada hasil 124,000 data (tulisan, artikel, jurnal, dan lain sebagainya) yang diupload di internet. ${ }^{45}$

(d) Keyword "Menolak Putusan MK Tentang Anak Diluar Kawin," mesin pencari Google menunjukkan 141,000 data (tulisan, artikel, jurnal, dan lain sebagainya) yang diupload di internet. ${ }^{46}$

(e) Keyword “Kontroversi Putusan MK Tentang Anak Diluar Kawin," mesin pencari Google menunjukkan 118,000 data (tulisan, artikel, jurnal, dan lain sebagainya) yang diupload di internet. ${ }^{4}$

(f) Keyword "Kontroversi Putusan MK Tentang Anak Diluar Kawin," mesin pencari Google menunjukkan 118,000 data (tulisan, artikel, jurnal, dan lain sebagainya) yang diupload di internet: ${ }^{48}$

\footnotetext{
${ }^{43}$ https: / / www.google.com/search?q=Putusan $\% 20 \mathrm{MK} \% 20$ tentang $\% 20$ anak $\% 20$ diluar $\% 20$ perkawinan\&i $\mathrm{e}=$ utf-8\&oe=utf-8\&aq=t\&rls=org.mozilla:en-US:official\&client=firefox-a\&source=hp\&channel=np

${ }^{44}$ https: / www.google.com/search?q=Putusan $\% 20 \mathrm{MK} \% 20$ tentang $\% 20$ anak $\% 20$ diluar $\% 20$ nikah\&ie=utf $-8 \&$ oe $=$ utf- $8 \&$ aq $=$ t\&rls $=$ org. mozilla:en - US:official\&client $=$ firefox -

a\&source $=$ hp\&channel $=$ np $\#$ channel $=$ np\&q $=$ Tanggung + Jawab + Ayah + Biologis + Pasca + Putusan + MK\&rls $=$ or g.mozilla:en-US:official

${ }^{45}$ https: / / www.google.com/search?q=Putusan $\% 20 \mathrm{MK} \% 20$ tentang $\% 20$ anak $\% 20$ diluar $\% 20$ nikah\&ie=utf $-8 \&$ oe $=$ utf- $8 \&$ aq $=$ t\&rls $=$ org. mozilla:en $-U S:$ official\&client $=$ firefox -

a\&source $=$ hp\&channel $=$ np $\#$ channel $=n p \& q=$ Menerima + Putusan + Mk + Tentang + Anak + Diluar + Kawin\&rls $=\mathrm{O}$ rg.mozilla:en-US:official

${ }^{46}$ https: / / www.google.com/search?q=Putusan $\% 20 \mathrm{MK} \% 20$ tentang $\% 20$ anak $\% 20$ diluar $\% 20$ nikah\&ie $=$ utf $-8 \&$ oe $=$ utf- $8 \&$ aq $=$ t\&rls $=$ org. mozilla:en $-U S:$ official $\&$ client $=$ firefox -

a\&source $=$ hp\&channel $=$ np\#channel $=$ np\&q $=$ Menolak + Putusan + Mk + Tentang + Anak + Diluar + Kawin\&rls $=$ org .mozilla:en-US:official

${ }^{47}$ https: / / www.google.com/search?q=Putusan $\% 20 \mathrm{MK} \% 20$ tentang $\% 20$ anak $\% 20$ diluar $\% 20$ perkawinan\&i $\mathrm{e}=$ utf-8\&oe=utf-8\&aq=t\&rls=org.mozilla:en-US:official\&client=firefox-

a\&source $=$ hp\&channel=np\#channel $=$ np\&q $=$ Kontroversi + Putusan $+M K+$ Tentang + Anak + Diluar + Kawin\&rls $=$ org.mozilla:en-US:official

${ }^{48}$ https: / www.google.com/search?q=Putusan $\% 20 \mathrm{MK} \% 20$ tentang $\% 20$ anak $\% 20$ diluar $\% 20$ nikah\&ie=utf $-8 \&$ oe $=$ utf- $8 \&$ aq $=$ t\&rls $=$ org. mozilla:en-US:official\&client $=$ firefox -

a\&source $=$ hp\&channel $=$ np\#channel $=$ np\&q $=$ Kontroversi + Putusan $+M K+$ tentang + anak + diluar + kawin\&rls $=$ or g.mozilla:en-US:official
} 


\section{(2) Putusan MK No. 47-81/PHPU.A-VII/2009 Tentang Sistem Noken}

(a) Keyword "Putusan MK Tentang Sistem Noken," mesin pencari Google menunjukkan 2,620 data (tulisan, artikel, jurnal, dan lain sebagainya) yang diupload di internet. 49

(b) Keyword "Menolak Putusan MK Tentang Sistem Noken," mesin pencari Google menunjukkan 4,550 data (tulisan, artikel, jurnal, dan lain sebagainya) yang diupload di internet. 50

(c) Keyword "Menerima Putusan MK Putusan MK Tentang Sistem Noken," mesin pencari Google menunjukkan 4,700 data (tulisan, artikel, jurnal, dan lain sebagainya) yang diupload di internet. ${ }^{51}$

(d) Keyword "Menolak Putusan MK Tentang Sistem Noken di Yahukimo," mesin pencari Google menunjukkan 178 data (tulisan, artikel, jurnal, dan lain sebagainya) yang diupload di internet. 52

(e) Keyword "Menerima Putusan MK Tentang Sistem Noken di Yahukimo," mesin pencari Google menunjukkan 187 data (tulisan, artikel, jurnal, dan lain sebagainya) yang diupload di internet. ${ }^{53}$

(f) Keyword "Putusan MK Tentang Sistem Noken di Yahukimo Papua," mesin pencari Google menunjukkan 216 data (tulisan, artikel, jurnal, dan lain sebagainya) yang diupload di internet. ${ }^{54}$

Dari data tersebut jelas terlihat bahwa putusan MK tentang anak diluar kawin lebih kontroversi daripada putusan yang terkait dengan sistem noken di Yahukimo Papua. Dari data Google bisa diketahui bahwa "pembicaraan" mengenai putusan MK tentang anak diluar kawin jauh lebih banyak ketimbang "pembicaraan" putusan MK tentang sistem noken.

\footnotetext{
${ }^{49} \mathrm{https}$ / / www.google.com/search?q=Putusan $\% 20 \mathrm{MK} \% 20$ tentang $\% 20$ anak $\% 20$ diluar $\% 20$ nikah\&ie $=$ utf $-8 \&$ oe $=$ utf-8\&aq $=$ t\&rls $=$ org. mozilla:en $-U S:$ official\&client $=$ firefox-

a\&source $=$ hp\&channel $=$ np \# channel $=$ np\&q $=$ putusan $+M K+$ tentang + sistem + Noken\&rls=org.mozilla:en US:official

${ }^{50}$ https: / /www.google.com/search?q=Putusan $\% 20 \mathrm{MK} \% 20$ tentang $\% 20$ anak $\% 20$ diluar $\% 20$ nikah\&ie=utf $-8 \&$ oe $=$ utf- $8 \&$ aq $=$ t\&rls $=$ org. mozilla:en $-U S:$ official $\&$ client $=$ firefox -

a\&source $=$ hp\&channel $=$ np $\#$ channel $=$ np\&q $=$ menolak + putusan $+\mathrm{MK}+$ tentang + sistem + Noken\&rls $=$ org.mozill a:en-US:official

${ }^{51}$ https: / / www.google.com/search?q=Menerima $\% 20$ putusan $\% 20 \mathrm{MK} \% 20$ putusan $\% 20 \mathrm{MK} \% 20$ tentang $\%$ 20 sistem $\% 20$ Noken\&ie $=u t f-8 \&$ oe $=u t f-8 \& a q=t \& r l s=$ org. mozilla:en-US:official\&client=firefoxa\&source $=\mathrm{hp} \&$ channel $=\mathrm{np}$

${ }^{52}$ https: / /www.google.com/search?q=Menerima $\% 20$ putusan $\% 20 \mathrm{MK} \% 20$ putusan $\% 20 \mathrm{MK} \% 20$ tentang $\%$ 20 sistem $\% 20$ Noken\&ie $=$ utf- $8 \& o e=u t f-8 \& a q=t \& r l s=$ org. mozilla:en-US:official\&client $=$ firefox-

a\&source $=$ hp\&channel $=$ np \#channel $=$ np\&q $=$ Menolak + putusan $+M K+$ tentang + sistem + noken + di + yahukimo\& $\mathrm{rls}=$ org.mozilla:en-US:official

${ }^{53}$ https: / / www.google.com/search?q=Menerima $\% 20$ putusan $\% 20 \mathrm{MK} \% 20$ putusan $\% 20 \mathrm{MK} \% 20$ tentang $\%$ 20 sistem $\% 20$ Noken\&ie $=u t f-8 \& o e=u t f-8 \& a q=$ t\&rls $=$ org. mozilla:en-US:official\&client $=$ firefoxa\&source $=$ hp\&channel $=$ np $\#$ channel $=$ np\&q $=$ Menerima + putusan $+M K+$ tentang + sistem + noken + di + yahukimo \&rls=org.mozilla:en-US:official

${ }^{54}$ https: / / www.google.com/search?q=Menerima $\% 20$ putusan $\% 20 \mathrm{MK} \% 20$ putusan $\% 20 \mathrm{MK} \% 20$ tentang $\%$ 20 sistem $\% 20$ Noken\&ie $=$ utf-8\&oe $=u t f-8 \& a q=t \& r l s=$ org. mozilla:en-US:official\&client $=$ firefoxa\&source $=$ hp\&channel $=$ np $\#$ channel $=$ np\&q $=$ putusan $+M K+$ tentang + sistem + noken + di + yahukimo + papua\&rls =org.mozilla:en-US:official
} 
Selain itu, dengan menggunakan keyword "menolak" dan keyword "menerima" terhadap putusan MK tentang anak di luar kawin lebih banyak "pembicaraan" yang menolak daripada yang menerima. Namun hal tersebut tidak terjadi pada putusan MK tentang sistem noken di Yahukimo Papua. Dalam putusan tersebut, data google menunjukkan lebih banyak "pembicaraan" yang menerima putusan tersebut daripada "pembicaraan" yang menolak. Dengan demikian bisa disimpulkan bahwa fungsi MK sebagai agent of social change lebih bisa diterima daripada fungsi MK sebagai Instigator of social change.

\section{Penutup}

Dari uraian di atas, bisa disimpulkan bahwa Mahkamah Konstitusi Indonesia melalui putusan-putusannya terbukti telah mempengaruhi perubahan sosial di masyarakat. Dalam melakukan perubahan tersebut, MK sedikitnya memainkan dua peran, yaitu sebagai agent of social change dan sebagai Instigator of social change. MK memainkan peran sebagai Instigator of social change dibuktikan dengan adanya Putusan MK No. 46/PUU-VIII/ 2010 tentang Anak Di luar Kawin yang jelas-jelas mempengaruhi perubahan sosial dengan melawan hukum yang masih hidup dan berkembang di masyarakat. Anak diluar kawin yang sebelumnya hanya mempunyai hubungan keperdataan dengan ibunya dan keluarganya, sekarang dengan putusan tersebut juga mempunyai hubungan keperdataan dengan ayah biologis dan keluarganya.

Peran sebagai agent of social change bisa dilihat pada Putusan No. 4781/PHPU.A-VII/2009 tentang Sistem Noken. Sistem Noken dalam pemilu yang sejatinya merupakan sistem pemilihan secara aklamasi atau mempercayakan kepada kepala sukunya, sudah berlangsung ratusan tahun di bumi Yahukimo Papua. Tradisi seperti itu kemudian disahkan oleh MK sebagai bagian demokrasi di daerah tersebut. Dengan memberi "stempel" terhadap tradisis yang sudah berlangsung turun temurun itu, maka sejatinya MK telah menggunakan peran sebagai agent of social change.

Peneliti juga mencari tahu bagaimana tingkat penerimaan masyarakat terhadap kedua peran tersebut. dengan menggunakan metode penelitian yang sederhana yaitu dengan meminta bantuan mesin pencari google, dapat diketahui 
bahwa masyarakat lebih resisten terhadap putusan MK yang Instigator of social change ketimbang Putusan yang memerankan sebagai agent of social change. Kesimpulan ini diambil dari data google yang menunjukkan bahwa "pembicaraan" mengenai Putusan anak diluar kawin di internet jauh lebih banyak ketimbang “pembicaraan" putusan MK tentang sistem Noken.

Selain itu, dengan menggunkan keyword "menolak" dan keyword "menerima" terhadap putusan MK tentang anak dilaur kawin lebih banyak "pembicaraan" yang menolak daripada yang menerima. Namun hal tersebut tidak terjadi pada putusan MK tentang sistem noken di Yahukimo Papua. Dalam putusan tersebut, data google menunjukkan lebih banyak "pembicaraan" yang menerima putusan tersebut daripada "pembicaraan" yang menolak.

Tiga persoalan yang mengemuka di atas terjawab. Pertama, dari dua putusan yang dilakukan penelitian diketahui bahwa sebagai lembaga peradilan, MK mempunyai peran yang cukup besar dalam melakukan perubahan sosial terhadap Masyarakat. Kedua, dalam melakukan perubahan sosial tersebut, sedikitnya ada dua model yang dilakukan oleh MK, yaitu memainkan peran sebagai Instigator of Social Change dan Agent of Social Change. Dan, ketiga, ternyata masyarakat lebih suka peran MK sebagai Agent of Social Change daripada peran MK sebagai Instigator of Social Change.

\section{Daftar Pustaka}

\section{Buku}

Ashshofa, Burhan, Metode Penelitian Hukum, cet. ke-4, Rineka Cipta, Jakarta, 2004.

Cooter, Robert D., The Strategic Constitution, Princeton University Press, New Jersey, 2000.

Jacobs, Francis G., The Sovereignty of law: the European way, Cambridge University Press, London, 2007.

Kriekhof, Valerine J.L., dkk., "Metode Penelitian Hukum (Seri Buku Ajar)," Buku A, (Depok, Fakultas Hukum Universitas Indonesia, 2000).

Marzuki, Peter Mahmud, Penelitian Hukum, Prenada Media, Jakarta, 2005.

Mahfud MD, Moh., "Inilah Hukum Progresif Indonesia" dalam Moh. Mahfud MD, dkk, Dekonstruksi dan Gerakan Pemikiran Hukum Progresif, Thafa Media dan Konsorsium Hukum Progresif Universitas Diponegoro, Semarang, 2013. 
Rahardjo, Satjipto, Biarkan Hukum Mengalir: Catatan Kritis tentang Pergulatan Manusia dan Hukum, Penerbit Buku Kompas, Jakarta, 2007.

Riggs, Fred W., Administration in Developing Countries: The Theory of Prismatic Society Boston, Houghton Mifflin Company, 1964.

Rosenfeld, Michel, Constitutional Adjudication in Europe and the United States: Paradoxes and Contrasts, dalam European and US Constitutionalism, Georg Nolte (ed.), Cambridge University Press, New York, 2005.Rosenberg, Gerald N., The Hollow Hope: Can Courts Bring About Social Change?, Chicago, University of Chicago Press, 1991.

Soekanto, Soerjono, dan Sri Mamuji, Penelitian Hukum Normatif; Suatu Tinjauan Singkat, cet. ke-6, RajaGrafindo Persada, Jakarta, 2003.

Strauss, David A., The Living Constitution, New York: Oxford University Press, 2000.

Mahkamah Konstitusi, Refleksi 2013 dan Proyeksi 2014 Mahkamah Konstitusi Menjaga Independensi Mahkamah Konstitusi Menyongsong Pemilu 2014, Mahkamah Konstitusi, Jakarta, 2014.

\section{Jurnal}

Ghoffar, Abdul, “Kejujuran dalam Bingkai Hak Memilih-Dipilih (Pelajaran dari Pemilukada Bengkulu Selatan)", Jurnal Konstitusi Vol. 8 No. 1 Tahun 2011.

Munawaroh, Nafiatul, dan Maryam Nur Hidayati, “Integrasi Pengujian Peraturan Perundang-Undangan di Mahkamah Konstitusi sebagai Upaya Pembangunan Hukum Indonesia", Jurnal Hukum Ius Quia Iustum No. 2 Vol. 22 April 2015.

Sackville, Justice Ronald, Courts and Social Change, dalam Federal Law Review Volume 33. Content downloaded/printed from HeinOnline (http:/ / heinonline.org), Mon Jan 20 03:33:42 2014.

\section{Majalah}

Ghoffar, Abdul, Konstitusi Yang Bernyawa, Majalah Konstitusi Edisi Mei tahun 2012.

\section{Peraturan Perundang-undangan}

Kitab Undang-Undang Hukum Perdata (Burgerlijk Wetboek voor Indonesie)., hukum.unsrat.ac.id/uu/kolonial_kuh_perdata.pdf., diakses pada tanggal 22 Januari 2014.

Kompilasi Hukum Islam, hukum.unsrat.ac.id/ma/kompilasi.pd., diakses pada tanggal 22 Januari 2014.

\section{Putusan Pengadilan}

Putusan MK Nomor 46/PUU-VIII/2010 Tentang Pengujian UU No. 1 Tahun 1974 tentang Perkawinan. 
Putusan MK Nomor 47-81/PHPU.A-VII/2009 Tentang Perselisihan Hasil Pemilihan Umum Anggota Dewan Perwakilan Daerah.

\section{Internet:}

Bagus Anwar Hidayatulloh, Kontroversi Putusan MK Tentang Pemilu Noken, http://hukum.kompasiana.com/2013/11/24/kontroversi-putusan-mktentang-pemilu-noken--610900.html. Diakses pada 21 Januari 2014.

Mengenal Noken Tas dari Papua, http://www.qbaya.com/2013/12/mengenalnoken-tas-dari-papua.html, Diakses pada 21 Januari 2014.

https:/ / www.google.com/search?q=Putusan\%20MK\%20tentang\%20anak\%20dil uar $\% 20$ perkawinan\&ie $=$ utf $-8 \& o e=u t f-8 \& a q=t \& r l s=$ org. mozilla:en-

US:official\&client $=$ firefox-a\&source $=h p \& c h a n n e l=n p$

https:/ / www.google.com/search?q=Putusan\%20MK\%20tentang\%20anak\%20dil uar\%20nikah\&ie=utf-8\&oe=utf-8\&aq=t\&rls=org. mozilla:en-

US:official\&client=firefox-

a\&source $=$ hp\&channel $=$ np\#channel $=$ np\& $q=$ Tanggung $+J a w a b+$ Ayah + Bio logis+Pasca+Putusan+MK\&rls=org.mozilla:en-US:official

https:/ / www.google.com/search?q=Putusan\%20MK\%20tentang\%20anak\%20dil uar\%20nikah\&ie=utf-8\&oe=utf-8\&aq=t\&rls=org.mozilla:en-

US:official\&client=firefoxa\&source $=\mathrm{hp} \&$ channel $=$ np\#channel $=\mathrm{np} \& \mathrm{q}=$ Menerima + Putusan $+\mathrm{Mk}+\mathrm{Te}$ ntang+Anak+Diluar+Kawin\&rls=org.mozilla:en-US:official

https:/ /www.google.com/search?q=Putusan\%20MK\%20tentang\%20anak\%20dil uar\%20nikah\&ie=utf-8\&oe=utf-8\&aq=t\&rls=org.mozilla:enUS:official\&client=firefoxa\&source $=$ hp\&channel=np\#channel $=n p \& q=$ Menolak + Putusan + Mk + Tent ang+Anak+Diluar+Kawin\&rls=org.mozilla:en-US:official

https:/ / www.google.com/search?q=Putusan\%20MK\%20tentang\%20anak\%20dil uar\%20perkawinan\&ie=utf-8\&oe=utf-8\&aq=t\&rls=org.mozilla:enUS:official\&client=firefoxa\&source $=\mathrm{hp} \&$ channel $=\mathrm{np}$ \#channel $=\mathrm{np} \& \mathrm{q}=$ Kontroversi + Putusan $+\mathrm{MK}+\mathrm{T}$ entang+Anak+Diluar+Kawin\&rls=org.mozilla:en-US:official

https:/ / www.google.com/search?q=Putusan\%20MK\%20tentang\%20anak\%20dil uar\%20nikah\&ie=utf-8\&oe=utf-8\&aq=t\&rls=org.mozilla:enUS:official\&client=firefoxa\&source $=\mathrm{hp} \&$ channel $=$ np\#channel $=\mathrm{np} \& \mathrm{q}=$ Kontroversi + Putusan $+\mathrm{MK}+\mathrm{t}$ entang+anak+diluar+kawin\&rls=org.mozilla:en-US:official

https:/ / www.google.com/search?q=Putusan\%20MK\%20tentang\%20anak\%20dil uar\%20nikah\&ie=utf-8\&oe=utf-8\&aq=t\&rls=org.mozilla:enUS:official\&client=firefoxa\&source $=$ hp\&channel $=$ np\#channel $=$ np\& $q=$ putusan $+M K+$ tentang + siste $\mathrm{m}+$ Noken\&rls=org.mozilla:en-US:official 
https:/ / www.google.com/ search?q=Putusan \%20MK\%20tentang\%20anak\%20dil uar\%20nikah\&ie=utf-8\&oe=utf-8\&aq=t\&rls=org.mozilla:enUS:official\&client=firefoxa\&source $=$ hp\&channel $=$ np\#channel $=n p \& q=$ menolak + putusan $+M K+$ tent ang+sistem+Noken\&rls=org.mozilla:en-US:official

https:/ / www.google.com/ search?q=Menerima \%20putusan \%20MK\%20putusan $\% 20 \mathrm{MK} \% 20$ tentang $\% 20$ sistem $\% 20$ Noken\&ie=utf-8\&oe=utf$8 \& a q=$ t\&rls=org.mozilla:en-US:official\&client=firefoxa\&source $=$ hp\&channel $=$ np

https:/ / www.google.com/search?q=Menerima\%20putusan \%20MK\%20putusan $\% 20 \mathrm{MK} \% 20$ tentang $\% 20$ sistem $\% 20$ Noken\&ie=utf-8\&oe=utf$8 \& a q=t \& r l s=$ org.mozilla:en-US:official\&client=firefoxa\&source $=$ hp\&channel $=n p \#$ channel $=n p \& q=$ Menolak + putusan $+M K+$ tent ang+sistem+noken+di+yahukimo\&rls=org.mozilla:en-US:official

https:/ / www.google.com/ search?q=Menerima \%20putusan \%20MK\%20putusan $\% 20 \mathrm{MK} \% 20$ tentang $\% 20$ sistem $\% 20$ Noken\&ie=utf-8\&oe $=$ utf$8 \& a q=$ t\&rls=org.mozilla:en-US:official\&client=firefoxa\&source $=$ hp\&channel $=$ np\#channel $=n p \& q=$ Menerima + putusan $+M K+$ ten tang+sistem+noken+di+yahukimo\&rls=org.mozilla:en-US:official

https:/ / www.google.com/search?q=Menerima\%20putusan \%20MK\%20putusan $\% 20 \mathrm{MK} \% 20$ tentang $\% 20$ sistem $\% 20$ Noken\&ie=utf-8\&oe=utf$8 \& a q=t \& r l s=$ org.mozilla:en-US:official\&client=firefoxa\&source $=$ hp\&channel $=$ np\#channel $=n p \& q=$ putusan $+M K+$ tentang + siste $\mathrm{m}+$ noken+di+yahukimo+papua\&rls=org.mozilla:en-US:official. 